\title{
STELLILABIUM ERRATUM, A COMEDY OF BLUNDERS
}

\author{
ROBERT L. DRESSLER \\ Missouri Botanical Garden, P.O. Box 299, St. Louis, Missouri 63166-0299, U.S.A. \\ Florida Museum of Natural History; Marie Selby Botanical Gardens \\ Mailing address: 21305 NW 86th Ave., Micanopy, Florida 32667, U.S.A.
}

\begin{abstract}
RESUMEN. Se describe Stellilabium erratum, una especie de Tapantí y el valle del Río Pejibaye, de planta y flores relativamente grandes para el género. La columna y el labelo son trilobados y los lóbulos laterales de la columna llevan setas conspicuas.
\end{abstract}

\section{KeY Words: Orchidaceae, Stellilabium sect. Taeniorhachis, Stellilabium erratum, Costa Rica}

The collection of tiny orchids for botanical study is frustrating. If it is available, one gathers what seems to be abundant material but when the plants are dried, there is little left. The plant to be described here is large for a Stellilabium, being about $20 \mathrm{~cm}$ tall and branched. Even so, each plant may have few flowers at a given moment. I first saw the species along the Río Pejibaye at La Selva de Cartago in 1984, where we were mistakenly calling the locality Taus, which I mistakenly spelled as Taos. Being reluctant to gather enough material for a good specimen, I convinced myself that it must be a named species. We photographed a flower, and a photograph was published in the Field Guide (Plate 30, fig. 4, Dressler 1993) as Stellilabium bullpenense Atwood, which it is not by any stretch of the imagination. A few minutes after photographing that Stellilabium, we crossed a pasture and found another species at the edge of the forest. This tiny plant, with a single flower, was pressed and I later made a label for it, as number 310 of the plants collected by Dressler and Biología 350 and sent the label to the University of Costa Rica Herbarium (USJ), where the first set of specimens is deposited.

When I looked at the Stellilabium specimens at USJ in 1999, I found my label number 310 mounted with a plant of the large plant from the gallery forest. Someone else had pressed a specimen, and the tiny plant for which the label was intended was simply lost among the newspapers.

Later specimens were collected by Dressler and
Mora in 1991, by Atwood and Mora in 1992, and by Pupulin, Spadari and the Orchidology Course in 2000. The best of these specimens originally had several flowers but they were destroyed by insects. The remaining specimens have only a few flowers, but the label of Atwood \& Mora 4202 mentions two flowers in alcohol. I asked Franco Pupulin to search for the flowers in alcohol, and he found them to be the same as his own collection from the same locality. There is not much good material of this species, but it is more than is available of most other Central American species of Stellilabium and with Franco's excellent drawing it can finally receive a name.

Stellilabium (Taeniorhachis) erratum Dressler, $s p$. nov. $\quad$ FIG. 1.

TYPE: Costa Rica. Cartago: Cantón Paraíso, Dist. Orosi, Tapantí, Sendero Oropéndola, en P. N. Tapantí, 1350 m, 2 nov. 1992, epífita, flores moradas, J. T. Atwood \& D. E. Mora 4202 (holotype, USJ).

Rhachis alata, labellum trilobatum, medio inflatum; columna trilobata, lobulis lateralibus setis stellatis praedita, lobulo medio hispido.

Roots flattened, 1.5-2 mm wide; leaves 16-37 x 3$4 \mathrm{~mm}$, elliptic-oblanceolate, acute; stems basally terete, then sulcate; peduncular bracts 1.8-2.4 x 1.5 $\mathrm{mm}$, acute; rachis flattened, 1-1.2 $\mathrm{mm}$ wide, up to $16 \mathrm{~cm}$ long; floral bracts $1-1.2 \times 1.3 \mathrm{~mm}$, triangular, acute; pedicel and ovary $6.5 \mathrm{~mm}$; flowers dark wine-purple; dorsal sepal 3-3.5 x 2-2.2 mm, ovate, 


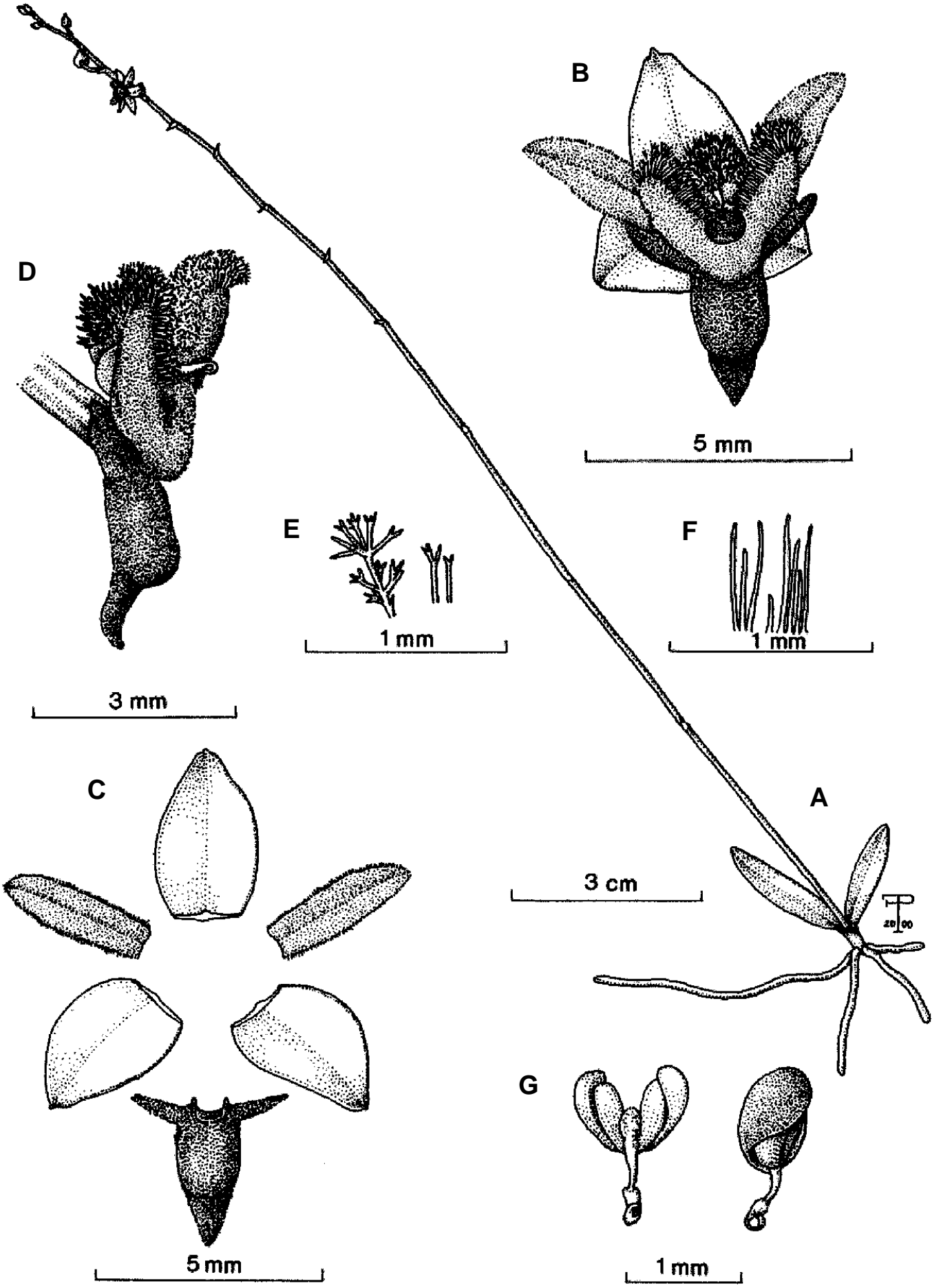

Figure 1. Stellilabium erratum Dressler. A - Habit. B - Flower. C - Perianth parts flattened. D - Column and lip, lateral view. E - Bristles of lateral lobes of column. F. Bristles of midlobe of column. G. Pollinarium without and with anther cap. Based on Pupulin et al. 2266. 
subacute; lateral sepals 3-4 x 1.6-2 mm, obliquely ovate, obtuse, apiculate; petals 3.3-3.5 x 0.9-1.1 $\mathrm{mm}$, narrowly elliptic-oblong, subacute, margins ciliate; lip 3-3.5 x 3-3.3 mm, 3-lobed, lateral lobes 1.3-2.5 x 0.4-0.5 mm, lanceolate, fleshy, papillose, midlobe 2.5-3 x 1.5-2.5 mm, ovate-triangular, acuminate, thickened in middle, puberulent-papillose; column 3-lobed, lateral lobes 1.3-1.5 x 0.4-0.8 $\mathrm{mm}$, oblong, flattened, the dorsal margins with dense band of stellate bristles ca. $0.7 \mathrm{~mm}$ long, midlobe rounded, ca. $1.5 \mathrm{~mm}$, bristles simple, ca. $0.4 \mathrm{~mm}$; capsule ovoid, ca. 7 × $3 \mathrm{~mm}$, including beak ca. $1.5 \mathrm{~mm}$, fruiting pedicel ca. $3 \mathrm{~mm}$.

Among Central American species of Stellilabium, S. erratum is distinguished by its large size (for a Stellilabium), by the deeply 3-lobed lip and the deeply 3-lobed column. The 3-lobed column would suggest its placement in Dipterostele, according to Garay and Romero (1998), but none of the species described from South America has the flattened, tapeworm-like rachis of the Central American complex. The section Taeniorhachis has been proposed for the Central American group (Dressler 1999). The available samples of DNA are very few (one species each of Dipterostele in the strict sense, Stellilabium in the strict sense and Taeniorhachis), but the analysis does suggest that the three may be distinct groups (N. H. Williams, pers. comm.)
Further and better samples, though, may well show that all three are subgroups of Telipogon in the broad sense. The epithet erratum, or error, refers to the improbable series of errors that started when we first saw the plant by the Río Pejibaye.

PARATYPES: Same locality as type, $1200 \mathrm{~m}, 9$ apr. 2000, F. Pupulin, L. Spadari y Curso de Orquideología 2266 (USJ). "Taos," altura aprox. 1000 m, 11 dic. 1984, por el borde entre selva y potrero, R. L. Dressler y Biología 350 no. 310 (USJ). La Selva. Valle del Río Pejibaye, elev. aprox. 1000 m, 18 marzo 1991, epífita, cerca del río, flores morado-rojo, $R$. L. Dressler y D. E. Mora de Retana 6136 (USJ).

ACKNOWLEDGEMENTS. I am very much indebted to the late Dora Emilia Mora, for helping me to reach this and many other interesting localities, and Franco Pupulin for the excellent drawing.

\section{Cited Literature}

Dressler, R. L. 1993. Field guide to the orchids of Costa Rica and Panama. Ithaca, Cornell University Press.

Dressler, R. L. 1999. A reconsideration of Stellilabium and Dipterostele. Harvard Pap. Bot. 4: 469-473.

Garay, L. A., \& G. A. Romero-González. 1998. Schedulae Orchidum. Harvard Pap. Bot. 3: 53-62. 